\title{
ON SOME NEW WEIGHTED EULER SEQUENCE SPACES AND COMPACT OPERATORS
}

\author{
METIN BAŞARIR, EMRAH EVREN KARA AND ŞÜKRAN KONCA
}

Abstract. In this paper, we define some new Euler sequence spaces and construct Schauder basis of these spaces. Moreover, we determine their $\beta$-duals and characterize some related matrix classes. Finally, we give the characterization of some classes of compact operators on these spaces by using the Hausdorff measure of noncompactness.

Mathematics subject classification (2010): 46B45, 46B15, 46B50.

Keywords and phrases: BK space, matrix transformation, Euler sequence spaces, compact operator, Hausdorff measure of noncompactness.

\section{REFERENCES}

[1] B. Altay AND F. BAŞAR, Some paranormed sequence spaces of non-absolute type derived by weighted mean, J. Math. Anal. Appl. 319, 2 (2006), 494-508.

[2] B. AltAy AND F. BAŞAR, Some Euler sequence spaces of non-absolute type, Ukrainian Math. J. 57, 1 (2005), 1-17.

[3] B. Altay, F. Başar And M. Mursaleen, On the Euler sequence spaces which include the spaces, $\ell_{p}$ and $\ell_{\infty}, I$, Inform Sci. 176, 10 (2006), 1450-1462.

[4] F. BAŞAR AND M. KIRIŞÇI, Almost convergence and generalized difference matrix, Comput. Math. Appl. 61, 3 (2010), 602-611.

[5] M. BAŞARIR AND E. E. KARA, On some difference sequence spaces of weighted means and compact operators, Ann. Funct. Anal. 2, 2 (2011), 116-131.

[6] M. BAŞARIR AND E. E. KARA, On compact operators on the Riesz $B^{(m)}$ difference sequence space, Iranian J. Sci. Technol. 35, A4 (2011), 279-285.

[7] M. BAŞARIR AND E. E. KARA, On the B difference sequence space derived by generalized weighted mean and compact operators, J. Math. Anal. Appl. 391, 1 (2012), 67-81.

[8] M. BAŞARIR AND E. E. KARA, On compact operators on the Riesz $B^{(m)}$ difference sequence spaces II, Iranian J. Sci. Technol. 36, A3 (2012), 371-376.

[9] S. DemiriZ, C. ÇAKAn, On some new paranormed Euler sequence spaces and Euler core, Acta Math. Sin. (Engl. Ser.) 26, 7 (2010), 1207-1222.

[10] I. DJolović AND E. Malkowsky, Matrix transformations and compact operators on some new $m^{\text {th }}$ order difference sequence spaces, Appl. Math. Comput. 198, 2 (2008), 700-714.

[11] E. E. KARA AND M. BAŞARIR, On compact operators and some Euler $B^{(m)}$ difference sequence spaces, J. Math. Anal. Appl. 379, 2 (2011), 499-511.

[12] E. E. KARA, M. ÖZTÜRK AND M. BAŞARIR, Some topological and geometrical properties of generalized Euler sequence spaces, Math. Slovaca 60, 3 (2010), 385-398.

[13] V. KARAKAYA AND H. POLAT, Some new paranormed sequence spaces defined by Euler and difference operators, Acta Sci. Math. (Szeged) 76, 1-2 (2010), 87-100.

[14] R. LASHKARIPOUR AND G. TALEBI, Lower bound for matrix operators on the Euler weighted sequence space $e_{w, p}^{\theta}(0<p<1)$, Acta Sci. Math. (Szeged) 61, 1 (2012), 1-12.

[15] B. De Malafosse And E. MALKOWSKy, On the measure of noncompactness of linear operators in spaces of strongly $\alpha$-summable and bounded sequences, Period. Math. Hungar. 55, 2 (2007), 129148. 
[16] E. MALKOWSKY AND V. RAKoČEVIĆ, An introduction into the theory of sequence spaces and measures of noncompactness, Zb. Rad. (Beogr.) Math. Institut. SANU 9, 17 (2000), 143-234.

[17] E. MALKOWSKY AND E. SAVAŞ, Matrix transformations between sequence spaces of generalized weighted mean, Appl. Math. Comput. 147, 2 (2004), 333-345.

[18] M. MuRSALEEN, Application of measure of noncompactness to infinite system of differential equations, Canadian Math. Bull. 2011, doi:10.4153/CMB-2011-170-7.

[19] M. Murs AleEn, F. BAŞAR AND B. Altay, On the Euler sequence spaces which include the spaces $\ell_{p}$ and $\ell_{\infty}, I I$, Nonlinear Anal. 65, 3 (2006), 707-717.

[20] M. Mursaleen, V. Karakaya, H. Polat AND N. ŞıMŞEK, Measure of noncompactness of matrix operators on some difference sequence spaces of weighted means, Comput. Math. Appl. 62, 2 (2011), 814-820.

[21] M. Mursaleen And A. K. Noman, Applications of the Hausdorff measure of noncompactness in some sequence spaces of weighted means, Comput. Math. Appl. 60, 5 (2010), 245-258.

[22] M. MurSAlEen AND A. K. NomAn, Applications of Hausdorff measure of noncompactness in the spaces of generalized means, Math. Inequal. Appl., Preprint.

[23] M. Mursaleen And A. K. Noman, Compactness by the Hausdorff measure of noncompactness, Nonlinear Anal. 73, 8 (2010), 2541-2557.

[24] M. Mursaleen And A. K. Noman, Compactness of matrix operators on some new difference sequence spaces, Linear Algebra Appl. doi:10.1016/j.laa.2011.06.014.

[25] M. Murs aleEn AND A. K. Noman, Compactness by the Hausdorff measure of noncompactness, Nonlinear Anal. 436, 1 (2012), 41-52.

[26] M. MURSALEEN AND A. K. NomAn, The Hausdorff measure of noncompactness of matrix operators on some BK spaces, Operators and Matrices 5, 3 (2011), 473-486.

[27] M. Mursaleen AND A. K. Noman, On $\sigma$-conservative matrices and compact operators on the space $V_{\sigma}$, Appl. Math. Lett. 24, 9 (2011), 1554-1560.

[28] M. Mursaleen And A. K. Noman, On generalized means and some related sequence spaces, Comput. Math. Appl. 61, 4 (2011), 988-999.

[29] M. Murs AleEn AND A. K. Noman, On some new difference sequence spaces of non-absolute type, Math. Comput. Modelling 52, 3-4 (2010), 603-617.

[30] M. MuRs ALEEN AND S. A. Mohiuddine, Applications of measures of noncompactness to the infinite system of differential equations in $\ell_{p}$ spaces, Nonlinear Anal. 75, 4 (2012), 2111-2115.

[31] H. POLAT AND F. BAŞAR, Some Euler spaces of difference sequences of order $m$, Acta Math. Sci. 27B, 2 (2007), 254-266.

[32] H. Polat And B. Altay, On some new Euler difference sequence spaces, Southeast Asian Bull. Math. 30, 2 (2006), 209-220.

[33] M. Stieglitz And H. TiEtz, Matrix transformationen von folgenräumen eine ergebnisübersicht, Math. Z. 154, 2 (1977), 1-16.

[34] A. Wilans Ky, Summability Through Functional Analysis, North-Holland Math. Studies 85, Amsterdam, 1984. 